\title{
Evaluation of the use of a vegetable oil in distribution transformers
}

\author{
Evaluación del uso de un aceite vegetal en transformadores de distribución
}

\author{
Diego Fernando-Navas ${ }^{1} \quad$ Diego Fernando Echeverry-Ibarra ${ }^{1} \quad$ Héctor Cadavid-Ramírez $^{1}$
}

Recibido 14 de marzo de 2012, aceptado 17 de julio de 2012

Received: March 14, $2012 \quad$ Accepted: July 17, 2012

\begin{abstract}
RESUMEN
Desde los inicios de los transformadores inmersos en líquido refrigerante, el fluido empleado por tradición ha sido el aceite de origen mineral. Sin embargo, en las últimas décadas se han unido esfuerzos en la búsqueda de alternativas que tengan un menor impacto en el medio ambiente y que a su vez satisfagan los requerimientos técnicos de aislamiento y refrigeración en los transformadores. Actualmente se encuentran en el mercado aceites aislantes de origen vegetal que pueden tener un menor impacto ambiental durante su uso y disposición final; no obstante, su elevado costo y su poco tiempo de uso han limitado su aplicación masiva.

En este trabajo se presenta la evaluación del comportamiento térmico de dos transformadores de distribución de diferente potencia inmersos en aceite dieléctrico de origen vegetal y se compara su desempeño con el de dos transformadores constructivamente iguales inmersos en aceite mineral. Los resultados obtenidos revelan que los transformadores cumplen con los requerimientos de la normatividad existente.
\end{abstract}

Palabras clave: Transformadores de distribución, aceite mineral, aceite vegetal, ester natural, MEF, medición de temperatura, comportamiento térmico.

\begin{abstract}
Since the start of transformers immersed in refrigerating liquid, the fluid traditionally used has been mineral oil. However, in recent decades, efforts have been joined in the search for alternatives with a lower environmental impact and which also satisfy the technical requirements of insulation and refrigeration in the transformers. Currently, insulating vegetable oils are available in the market, which may have lower environmental impact during their use and final disposition; nevertheless, their high cost and short time of use have limited their massive application.

This work presents the thermal behavior evaluation of two distribution transformers at different powers immersed in dielectric vegetable oil, comparing their performance with that of two constructively equal transformers immersed in mineral oil. The results obtained reveal that the transformers comply with the requirements of existing standards.
\end{abstract}

Keywords: Distribution transformers, mineral oil, vegetable oil, natural ester, FEM, temperature measurement, thermal behavior.

\section{INTRODUCTION}

Currently, transformers immersed in liquid mainly employ mineral oils given their proven good service performance and their relatively low cost when compared to other alternatives present in the market.
However, mineral oils have certain limitations like their low flashpoint, which conditions its use in indoor environments, and its low biodegradation, which may cause a high environmental impact during its use or final disposition.

\footnotetext{
1 Facultad de Ingeniería. Escuela de Ingeniería Eléctrica y Electrónica. Universidad del Valle. Calle 13 \# 100-00. Santiago de Cali, Colombia.E-mail: diego.navas@correounivalle.edu.co; diego.echeverry@correounivalle.edu.co; hector.cadavid@correounivalle.edu.co
} 
In recent years, the environmental aspect has become important and development of clean and technically functional technologies is of high demand. With the development of vegetable oils for use in electrical equipment, an alternative appears with advantages regarding safety and the environment [1-5]. Nonetheless, many questions arise when adopting this new technology: Is it necessary to redesign the transformer? How is the final disposition of these oils handled? Are these fluids compatible with the transformer's internal materials? Are they viable from the economic point of view? In this respect, several studies have been undertaken, mainly by manufacturers of these oils and by some research institutions and universities [6-15].

In the thermal evaluation, the literature shows a higher oil temperature rise in transformers immersed in vegetable oil [2]. This higher temperature rise would suggest a lower useful lifespan than for transformers with mineral oil; however, given that paper degrades much slower in the presence of vegetable oil these transformers could have an equal or greater useful lifetime than those immersed in mineral oil [5]. The possibility exists of overloading transformers that use vegetable oil. This fact is substantiated in that under nominal load conditions these transformers have a useful life that could be longer than that for those submerged in mineral oil, which would permit overloading the transformer at a given level and maintaining the same useful life as that of a transformer submerged in mineral oil [5-9].

In Colombia, research was conducted by Universidad del Valle in association with an electric sector company, which evaluated the thermal behavior of two conventional-type distribution, single-phase transformers immersed in dielectric vegetable oil and physical, chemical, and spectral tests were conducted, as well as experiments of oil accelerated aging, designed to analyze possible changes in the structure of the oil molecules [13].

This article presents the results of the thermal evaluation of the two distribution transformers submerged in Envirotemp ${ }^{\circledR}$ FR3 ${ }^{\mathrm{TM}}$ vegetable oil.

\section{EXPERIMENTATION}

This research used four single-phase distribution transformers with two different powers $(15 \mathrm{kVA}$ and $37.5 \mathrm{kVA}$ ) constructed by Rymel Ltd. These transformers have designs normally employed in Colombia. For each power rating, there was a transformer immersed in vegetable oil and another immersed in mineral oil; these were instrumented with optical fiber sensors. The instrumentation in the distribution transformers was conducted exclusively for investigative purposes (given its high costs) and it is not widely reported in the literature [16].

Based on prior experiences by the High-Voltage Research Group (GRALTA for its name in Spanish), in the instrumentation of a distribution transformer using thermocouples, five temperature measurement zones were defined; one located above the bottom of the tank, another below the upper oil level, two on the windings (high voltage and low voltage), and one in the core. The transformers were instrumented with sensors placed in previously selected points [16] (Figure 1); all the measurements, except for that of the core, were made with optical fiber sensors. To determine the placement of the sensors, also considering the technical viability of their installation, we had the thermal profiles of the transformer obtained through simulation with the finite elements ANSYS 11 software (Figures 2 and 3).

The transformers were evaluated through temperature elevation tests via the simulated-load method (short circuit) [17]; a total of 41 tests were run. To measure temperature with the optical fiber sensors we used a Neoptix Omniflex optical fiber system, we also used a platform developed in Labview, permitting the automation and control of the tests. Measurement of electrical variables and their incorporation onto the platform was carried out with Dranetz Encore 61000 equipment.

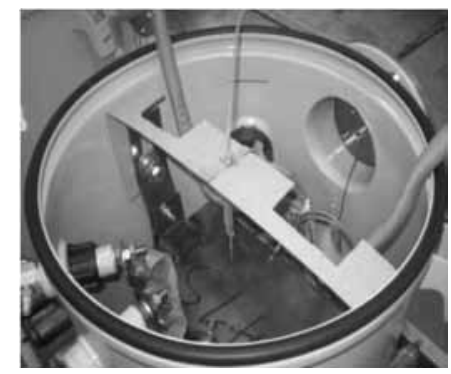

Figure 1. Instrumented distribution transformer. 


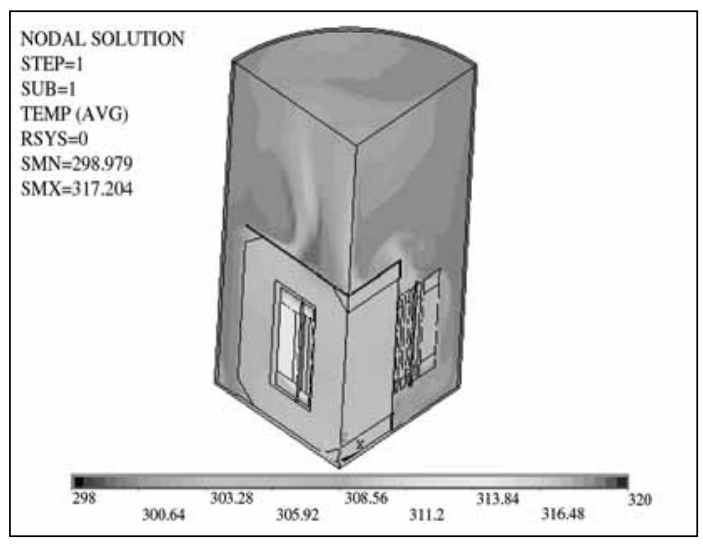

Figure 2. Thermal profiles in steady state of the $15-\mathrm{kVA}$ transformer submerged in mineral oil.

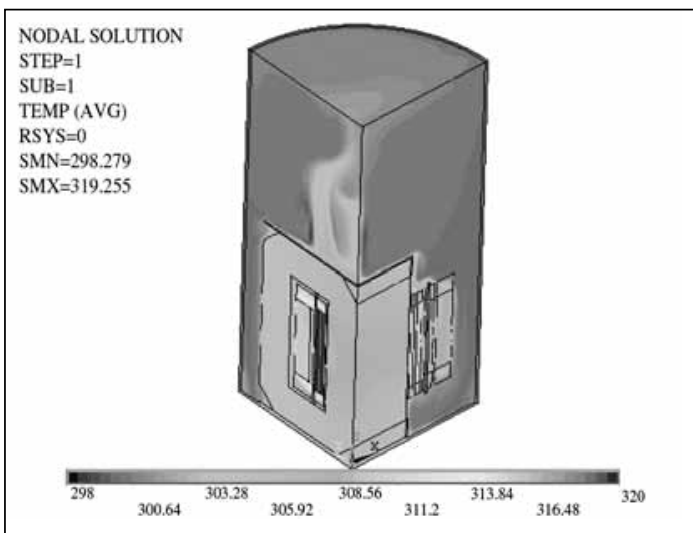

Figure 3. Thermal profiles in steady state of the 15-kVA transformer submerged in vegetable oil.

\section{RESULTS AND DISCUSSION}

The thermal behavior of the transformers evaluated in this research was conducted with respect to the temperature rise in the oil, windings, and in the hottest spot, under conditions of simulated load.

\section{Magneto-thermal simulation via MEF}

Among the main concerns at the start of the project were the temperature differences reached in the transformer under operation upon replacing mineral oil for vegetable oil because of the higher viscosity of vegetal oil. With this in mind, we conducted steady-state simulations implementing the geometry of a $15 \mathrm{kVA}$ transformer. The results of the simulations are shown in Figure 2 (mineral oil) and Figure 3 (vegetable oil). It can be noted that the maximum temperature in the mineral oil is de $317 \mathrm{~K}\left(44^{\circ} \mathrm{C}\right)$ and in the vegetable oil is $319 \mathrm{~K}$ $\left(46^{\circ} \mathrm{C}\right)$, which shows a maximum temperature rise of approximately $2^{\circ} \mathrm{C}$, agreeing with that obtained experimentally.

\section{Simulated load at constant reference Thermal behavior of oil}

For the transformers evaluated, the oil temperature rise was higher in the transformers submerged in vegetable oil; however, the greatest difference was noted for the $37.5 \mathrm{kVA}$ transformers where it was approximately $5{ }^{\circ} \mathrm{C}$. Figure 4 shows the result of the oil temperature rise obtained for each of the transformers analyzed.

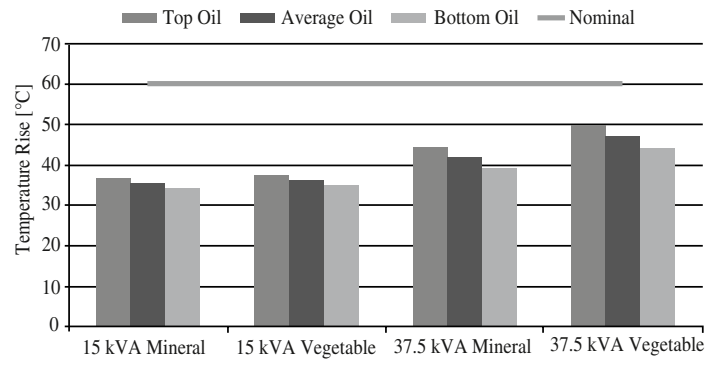

Figure 4. Oil temperature rise.

The oil temperature rise was smaller than the one specified by international standards. $\left(60^{\circ} \mathrm{C}\right)$ [18]. This may be explained because in Colombia big tanks are normally used to maintain the recommended electrical distances for their voltage levels; hence, they can be denominated "cold transformers". This situation would permit the use of vegetable oil without need for modifying transformer design.

\section{Thermal behavior of the winding}

The winding temperature rise was obtained by measuring winding resistance and from direct measurement by the optical fiber sensors placed in zones of interest defined by thermal simulations. Figure 5 shows the winding temperature rise in the transformers studied.

The difference between calculated values and those measured directly in the winding is because the calculation method estimates a temperature average, while the direct measurement shows a specific value. Values for the winding nominal average rise $(\Delta \theta \mathrm{W} / \mathrm{A}, \mathrm{R})$ both for the transformer submerged in mineral oil as for that in vegetable 


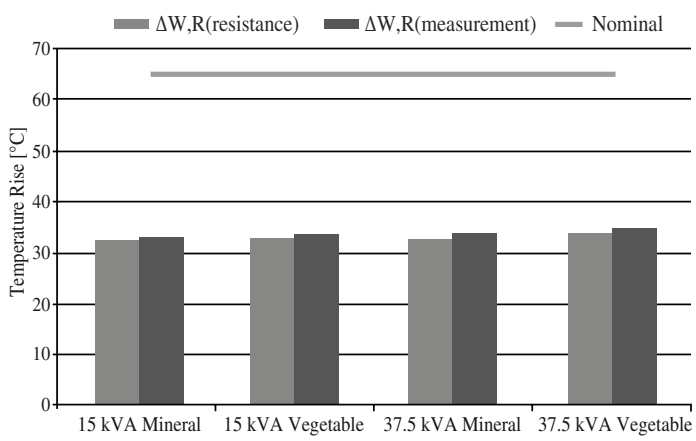

Figure 5. Nominal average winding temperature rise.

oil are below the $65{ }^{\circ} \mathrm{C}$ specified by national and international standards. However, somewhat higher temperature values are noted for the transformers submerged in vegetable oil.

\section{Thermal behavior of the hottest spot}

To estimate the hottest spot temperature rise, direct measurement may be used, whose implementation is usually not viable because of the amount of sensors required and because of their installation during the transformer manufacturing process. This investigation conducted thermal simulations by analyzing via finite elements to find higher temperature zones and then instrument the transformer during its manufacture. Figure 6 shows the record of temperatures and Figure 7 shows the hot spot temperature rise obtained from different IEC and IEEE criteria.

Values for hot-spot elevation $(\Delta \theta \mathrm{H} / \mathrm{A}, \mathrm{R})$ are below the $80{ }^{\circ} \mathrm{C}$ specified by national and international standards. Greater hot-spot elevations are found in transformers submerged in vegetable oil; however, the difference does not surpass $3{ }^{\circ} \mathrm{C}$ compared to transformers submerged in mineral oil.

Tables 1 and 2 show the results of calculating the hot-spot elevation on oil by using IEC and IEEE criteria. For IEC, we used an $\mathrm{H}=1.1$ factor, for the calculation we considered the higher temperature winding (U-X). For IEEE, we calculated the temperature average of the windings and added $15^{\circ} \mathrm{C}$ to this value. The value from direct measurement was obtained in the high-voltage winding.

\section{Two-level simulated load}

The thermal behavior of the transformers submerged in vegetable oil was also evaluated by using twolevel load curves characterized by a preload and an overload during a 4-hour period. The preload was

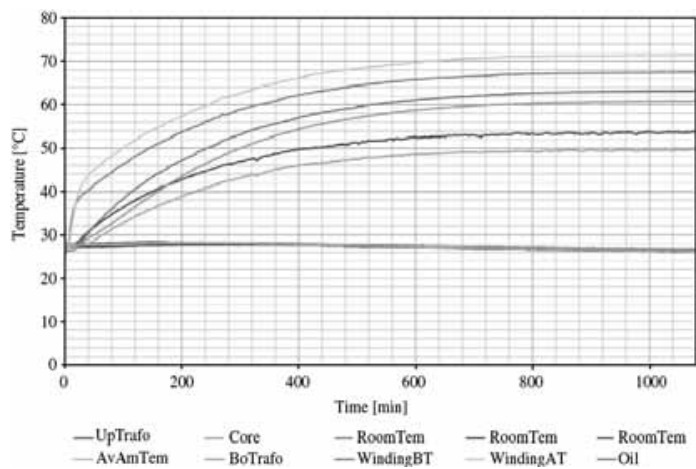

Figure 6. Temperatures recorded in a $15 \mathrm{kVA}$ transformer immersed in vegetable oil, test was performed at $100 \%$ power rating.

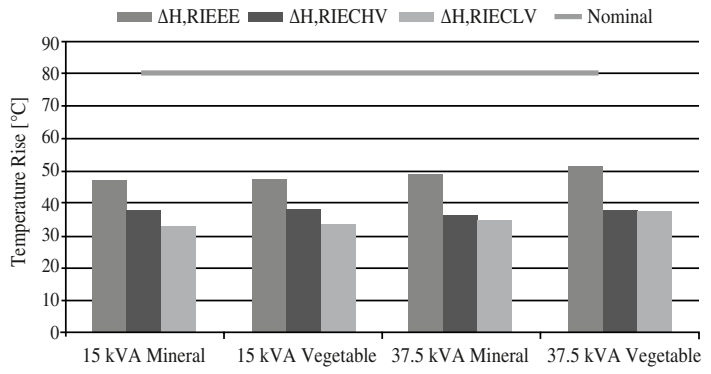

Figure 7. Nominal elevation of the hot spot per IEC and IEEE criteria.

Table 1. Calculation of the hot-spot elevation for the 15-kVA transformer.

\begin{tabular}{|c|c|c|c|c|c|c|}
\hline 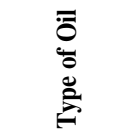 & $\stackrel{\Perp}{=}$ & 范 & 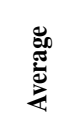 & 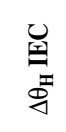 & 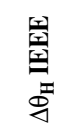 & 焉 \\
\hline Vegetable & 30.7 & 34.1 & 32.4 & 33.8 & 47,4 & 53.6 \\
\hline Mineral & 30.5 & 34.6 & 32.5 & 33.5 & 47.5 & 52.3 \\
\hline
\end{tabular}

Table 2. Calculation of the hot-spot elevation for the $37.5-\mathrm{kVA}$ transformer.

\begin{tabular}{|c|c|c|c|c|c|c|}
\hline 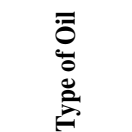 & İ & 感 & 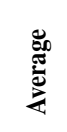 & 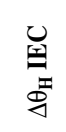 & 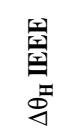 & 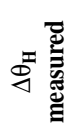 \\
\hline Vegetable & 34.2 & 38.4 & 36.3 & 37.6 & 51.3 & 60.0 \\
\hline Mineral & 31.7 & 36.6 & 34.1 & 34.8 & 49.1 & 53.8 \\
\hline
\end{tabular}

conducted at $70 \%$ and the overload at $125 \%$ of the power rating. In these experiments, we observed the thermal behavior in the upper part of the oil and in the high-voltage winding because these 
zones presented the greatest temperature rises in experiments of simulated load at constant reference. Figures 8 and 9 show the evolution of temperature in a 37.5-kVA transformer submerged in vegetable oil and mineral oil.

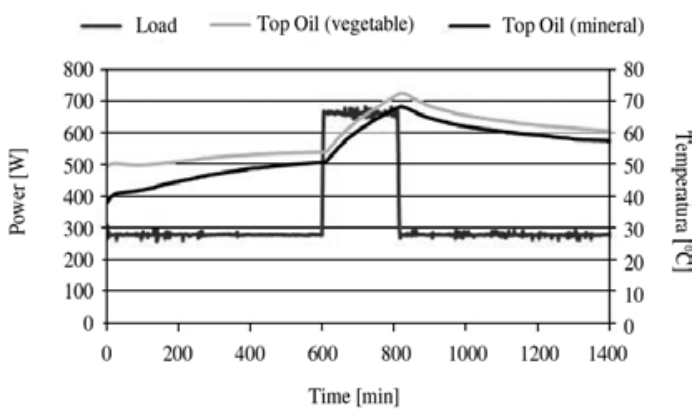

Figure 8. Thermal behavior of the upper level of oil in the 37.5-kVA transformers for two-level load.

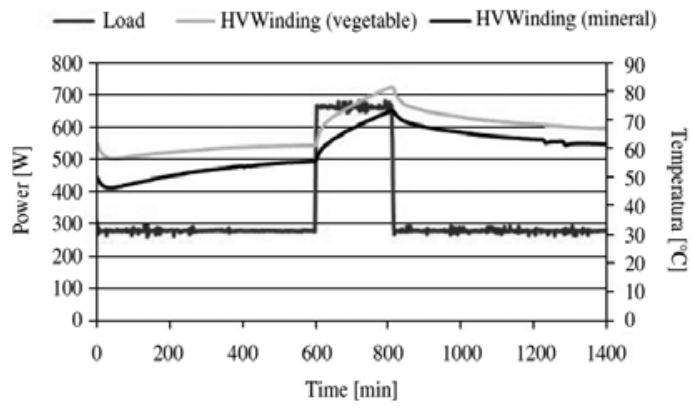

Figure 9. Thermal behavior in the high-voltage winding in the $37.5-\mathrm{kVA}$ transformers for a two-level load.

Upon ending the overload, a maximum $72{ }^{\circ} \mathrm{C}$ temperature value is present in the upper level of the oil and of $81{ }^{\circ} \mathrm{C}$ in the winding for the transformer submerged in vegetable oil. It was noted the measured temperature data are higher for the transformer submerged in vegetable oil. A difference of $4{ }^{\circ} \mathrm{C}$ was noticed between maximum temperature values in oil and of $8{ }^{\circ} \mathrm{C}$ for the windings. These results show that the temperature rise is greatest in the transformers submerged in vegetable oil. In spite of that, the temperature rises are within the nominal values suggested by national and international standards

Notwithstanding, to corroborate the normal operation from the dielectric point of view, it is necessary to revise the design of transformers, given that the physical, chemical, and dielectric properties of vegetable oil are different. The difference in the electric constants of the mineral and vegetable oils lead to the electric field distributions not being the same and perhaps the minimum distances required for their normal operation are not fulfilled.

\section{CONCLUSIONS}

Distribution transformers immersed in vegetable oil presented greater temperature rises compared to those immersed in mineral oil. The greatest temperature difference does not surpass $10 \%$. In spite of that, the temperature rises are within the nominal values suggested by national and international standards, therefore may be stated that the distribution transformers evaluated do not present inconveniences from the thermal point of view.

The results obtained are valid for the transformers tested; hence, it possible to have different results in other designs. Nevertheless, the distribution transformers tested may be considered as typical in Colombia for being "cold transformers".

We recommend submitting of transformers to dielectric tests like impulse voltage, applied voltage, and induced voltage.

\section{ACKNOWLEDGMENTS}

The authors thank the Instituto Colombiano para el Desarrollo de la Ciencia y la Tecnología Francisco José De Caldas (COLCIENCIAS) and Empresas Públicas de Medellín (EPM) for funding the project. Likewise, the authors thank RYMEL Ltd, Universidad del Valle and NEOPTIX.

\section{REFERENCES}

[1] T.V. Oommen. "Vegetable oils for liquid-filled transformers". IEEE Electrical Insulation Magazine. Vol. 18, pp. 6-11. 2002.

[2] C.P. McShane. "Vegetable-oil-based dielectric coolants". Industry Applications Magazine. Vol. 8, Issue 3, p. 8. 2002.

[3] T.V. Oommen, C.C. Claiborne, E.J. Walsh and J.P. Baker. "A new vegetable oil based transformer fluid: development and verification". Annual Report Conference on Electrical Insulation and Dielectric Phenomena. IEEE. Vol. 1, pp. 308-312. 2000. 
[4] T.V. Oommen, C.C. Claiborne and J.T. Mullen. "Biodegradable electrical insulation fluids". Electrical Insulation Conference and Electrical Manufacturing and Coil Winding Conference. Rosemont, IL: IEEE, pp. 465-468. 1997.

[5] J. Luksich. "Loading Guide A and B Factors for Envirotemp FR3 Fluid and Thermally Upgraded Kraft Insulation”. Report TP03DR-009. Cooper Power System, p. 3. 2003.

[6] D.P. Stockton, J.R. Bland, T. McClanahan, J. Wilson, D.L. Harris and C.P. McShane. "Natural Ester Transformer Fluids: Safety, reliability \& environmental performance". Petroleum and Chemical Industry Technical Conference, p. 7. 2007.

[7] A.R. Marulanda, M.A. Artigas, A. Gavidia, F. Labarca and N. Paz. "Study of the vegetable oil as a substitute for mineral oils in distribution transformer". Transmission and Distribution Conference and Exposition: Latin America, 2008, IEEE/PES, p. 6. 2008.

[8] J. Mak, L. Maciel, L.R. Franchini and V. Vagner. "Transformador de distribuição de maior vida útil e menor agressividade ambiental". IV WorkSpot, CIGRE Brasil, p. 8. 2006.

[9] C.P. McShane, M.N. Martins and J. Luksich. "Field Experience with Natural Ester (Vegetable Oil) Dielectric Fluid-The First Decade". IV Workspot-International Workshop on Power Transformers. CIGRE. Vol. 18, pp. 1-10. Brasil. 2006.

[10] CIGRÉ Report 436. "Experiences in Service with New Insulating Liquids". Working group A2.35, p. 84. 2010.

[11] M.B. Cecato Sttoco. "Avaliação do potencial de aplicação de óleos vegetais como fluidos isolantes em transformadores de distribuição da rede elétrica”. Programa de
Pós-Graduação em Engenharia e Ciência dos Materiais-PIPE. Universidade Federal do Paraná. Dissertação de Mestrado. Curitiba, p. 108. 2009.

[12] H.M. Wilhelm, L. Tulio, R. Jasinski and G. Almeida. "Aging Markers for In-service Natural Ester-based Insulating Fluids". IEEE Transactions on Dielectrics and Electrical Insulation. Vol. 18, Issue 3, p. 6. 2011.

[13] N.A. Gomez, R. Abonia, H. Cadavid and I.H Vargas. "Chemical and Spectroscopic Characterization of a Vegetable Oil used as Dielectric Coolant in Distribution Transformers". Journal of the Brazilian Chemical Society. Vol. $22 \mathrm{~N}^{\circ} 12$, pp. 22922303. 2011.

[14] ABNT NBR 15422 standard. "Insulating vegetable oil for electrical apparatus". Associação Brasileira de Normas Técnicas: Rio de Janeiro, Brazil. 2006.

[15] ASTM D6871. "Standard Specification for Natural (Vegetable Oil) Ester Fluids Used in Electrical Apparatus". USA. 2003.

[16] D.F. Navas, H. Cadavid and P.C. González. "Experiencias en la implementación de un sistema de medición de temperatura a través de fibras ópticas en transformadores de distribución". X Congreso Latinoamericano y VII Iberoamericano en Alta Tensión y Aislamiento Eléctrico. ALTAE. Cuba. Septiembre 2011.

[17] Transformers committee IEEE. "Standard Test Code for Liquid-Immersed Distribution, Power, and Regulating Transformers". IEEE Std C.57.12.90. IEEE Power \& Energy Society, pp. 5-29. New York. 2006.

[18] Transformers committee IEEE. "Guide for loading mineral oil-immersed overheadtype distribution transformer with $55{ }^{\circ} \mathrm{C}$ or $65^{\circ}$ C”. IEEE Std C.57.91, p. 100. 1995. 